\title{
BILINGUALISM OF INDONESIAN-ENGLISH IN ARTICLE TITLES: A CASE STUDY IN INDONESIAN MECHANICAL ENGINEERING ARTICLES
}

\author{
Yashinta Farahsani ${ }^{1, *}$, Margaretha Dharmayanti Harmanto ${ }^{2}$ \\ ${ }^{1}$ Department of Mechanical Engineering, Faculty of Engineering, Universitas Muhammadiyah Yogyakarta, Jl. \\ Brawijaya, Tamantirto, Kasihan, Bantul, Yogyakarta 55183, Indonesia \\ ${ }^{2}$ Department of Accounting, Faculty of Economics and Business, Universitas Muhammadiyah Yogyakarta, Jl. \\ Brawijaya, Tamantirto, Kasihan, Bantul, Yogyakarta 55183, Indonesia
}

\section{A R T ICLE INFO}

Keywords:

Bilingualism

Equivalence

Mechanical engineering articles

Untranslability

Article History:

Received: 01/10/2020

Accepted: 21/05/2021

Available Online:

31/05/2021

\begin{abstract}
A B S T RACT
Bilingualism happens not only orally but also in written Indonesian articles. Usually, the articles use Indonesian and English terms. Bilingualism even can be seen in the articles' titles. One of the fields that often use bilingual terms is found in Mechanical Engineering's articles. It happens because mechanical engineering has specialized terminology that sometimes untranslated into Indonesian terms. Many Indonesian experts have translated many English books with many variations of translation results. Therefore, the translation results are still questioned whether they are acceptable or not in Indonesian. This study aims to examine the factors of bilingualisms by observing titles of articles and finding the translation methods to translate the terminology from English to Indonesian. This study was qualitative research; by using questionnaires and observation, the research reveals that the main factor is untranslatability, where the English terminology cannot find its equivalent meaning in Indonesian. By using Molina and Albir's translation techniques, researchers reveal that the English terminologies can be translated in Indonesian using (1) amplification, (2) borrowing, (3) established equivalence, (4) calque, and (5) literal translation. This study concludes that the untranslatability problem can be solved when the experts try to use the accepted translation results rather than using English terms.
\end{abstract}

2442-305X / (C) 2021 The Authors, this is open access article under the (CC-BY-NC) license (https://creativecommons.org/licenses/by-nc/4.0/), DOI: 10.19105/ojbs.v15i1.3933

\footnotetext{
$\overline{\text { * Corresponding Author: }}$

Email address: yashinta_hime@yahoo.com (Y. Farahsani)
}

\section{A. Introduction}

Mechanical engineering is one of the fields that are rich in specialized terminology. In Indonesia, this field has many terms that borrow the English terms into Indonesian, even though it is untranslated. It is seen from many titles of scientific articles that use bilingualism in the form of both word and phrase, for example: Analisa Kekuatan Flange pada Sistem Pemipaan Primer Reaktor Triga 2000 Bandung; Unjuk Kerja 
Thermosyphon dengan Variasi Fluida Kerja; Pengaruh Wettability Surfaktan Nals Ampas Tebu pada Batuan Sandstone dalam Proses Enhanced Oil Recovery (EOR).

The term bilingualism in Indonesian is also called bilingual, which refers to using two languages or language codes. To be able to use two languages, of course, one must master both languages. First, their mother tongue or first language (L1), and the second is another language which is the second language (L2). People who can speak both languages are called bilinguals.

The term bilingual refers to the use of two languages by a speaker in his daily activities. $^{1}$ Bilingualism relates to language contact because bilingualism is the use of two languages by speakers alternately in making social contacts. Bilingualism is used in various aspects, one of which is science. Science is closely related to language because language is an intermediary. ${ }^{2}$ Bilingualism is defined as a speaker's ability to use two languages for communication. ${ }^{3}$ The use of more than one language alternately is motivated and determined by the

\footnotetext{
${ }^{1}$ Abdul Chaer and Leonie Agustina, Sosiolinguistik Perkenalan Awal (Jakarta: Rineka Cipta, 2004), 84. 2 Aleidine J. Moeller and Theresa Catalano, "Foreign Language Teaching and Learning," in International Encyclopedia of the Social \& Behavioral Sciences (Elsevier, 2015), 327-32, https://doi.org/10.1016/B978-0-08-097086-8.92082-8.

${ }^{3}$ L. S. Verplaetse and E. Schmitt, "Bilingualism and Learning," in International Encyclopedia of Education (Third Edition), ed. Penelope Peterson, Eva Baker, and Barry McGaw (Oxford: Elsevier, 2010), 355-60, https://doi.org/10.1016/B978-0-08044894-7.00508-X.
}

situations and conditions faced by the speakers in speaking actions.

The world's bilingual population grows along with the spread of internationalism in trade and travel, communications and mass media, immigration, and the interconnected global economy. ${ }^{4}$ In addition, bilingualism occurs due to the interaction of different linguistic groups, the fluidity of political and economic conditions in many countries, and the rapid changes in technology and telecommunications. ${ }^{5}$ Equally important, most bilinguals understand English because it is a global language that can function as an official language or a priority in foreign language teaching in many countries. ${ }^{6}$ The term 'bilingualism' is usually used to describe two individual languages, ${ }^{7}$ but can also be used for bilingual and multilingual situations. ${ }^{8}$ So, there is no consensus on what bilingualism is. These can be checked based on specific study objectives, categorization, and estimates. ${ }^{9}$

4 Colin Baker, Bilingualism: Definitions and Distinctions. Foundation of Bilingual Education and Bilingualism, 5th ed. (Bristol: Multilingual Matters, 2011), 66.

${ }^{5}$ Rafael Art Javier, The Bilingual Mind: Thinking, Feeling and Speaking in Two Languages (New York: Springer Science \& Business Media, 2007), 1.

6 David Crystal, English as a Global Language (Cambridge: Cambridge University Press, 2012), 4-5.

7 Baker, Bilingualism: Definitions and Distinctions. Foundation of Bilingual Education and Bilingualism, 67.

8 Betty Birner, "FAQ: Bilingualism | Linguistic Society of America," 2011, https://www.linguisticsociety.org/resource/faq-whatbilingualism.

${ }^{9}$ Andrea DeCapua and Ann Wintergerst, "SecondGeneration Language Maintenance and Identity: A Case Study," Bilingual Research Journal 32, no. 1 
The use of special terms that cannot be translated into Indonesian is usually caused by inappropriate or unacceptable translation problems. So far, some scientific books circulating in Indonesia still use foreign languages, especially English. ${ }^{10}$ Whereas the language is still not mastered by most of our society. Therefore, scientific books produced by translation play a significant role in the development of science and technology in our nation. However, many translations, especially from English into Indonesian, were not satisfactory. Several facts show that the translator does not master English as a source language (SL). As a result, writers, students, lecturers, or scientists in mechanical engineering tend to use English for specific terms rather than using Indonesian translations that they find less acceptable.

Most of the researches about untranslatability are related to cultural factors. One of the articles that discuss the untranslatability problem was carried out by Nur Utami S.K. ${ }^{11}$ who discusses the problem of non-translation in the translation of the Indonesian novel entitled Laskar Pelangi which was translated by Angie Kilbane into English as The

(2009): $5-24$ https://doi.org/10.1080/15235880902965672.

10 Sri Handayani, "Analisis Ideologi Penerjemahan dan Penilaian Kualitas Terjemahan Istilah Kedokteran dalam Buku 'Lecture Notes on Clinical Medicine'" (Master Thesis, Universitas Sebelas Maret, 2009).

${ }^{11}$ Nur Utami SK, "Cultural Untranslatability: A Study on the Rainbow Troops," Celt: A Journal of Culture, English Language Teaching \& Literature 14, no. 1 (2014):

48-62,
Rainbow Troops. This study is based on non-translation at the word level. For example, "Herein lay the appeal of the ancient and the legendary game of Tarak," ${ }^{12}$ Where the word Tarak is not translated into English because it is a term of ecological culture, therefore, the translator uses several translation strategies in translating Laskar Pelangi novel. They translate more general words, more neutral / less expressive words, cultural substitution, loanwords or loanwords plus explanations, paraphrasing using related words, unrelated paraphrasing, omissions, and illustrations.

Apart from that, Nafisah also researched matching search methods in the translation of the novel "God Sees the Truth, But Waits" by Tolstoy into Indonesian. ${ }^{13}$ In her research, the authors state that there are six translation methods used in word matching, namely (1) semantic translation, communicative translation, (3) literal translation, (4) adaptation, (5) free translation, and (6) word for word translation. Among the six methods, semantic translation was used the most, with 78 data or about $42.2 \%$.

In each data analysis, the author refers to Bell, who divides the level of

\footnotetext{
${ }^{12}$ Andrea Hirata, The Rainbow Troops, trans. Angie Kilbane (New York: Sarah Crichton Book, 2009), 132.

${ }^{13}$ Nuharani Dyah Nafisah, Rudi Hartono, and Issy Yuliasri, "Translation Methods and Degree of Equivalence in English-Indonesian Translation of Leo Tolstoy's "God Sees the Truth But Waits"," Rainbow: Journal of Literature, Linguistics and Culture Studies 7, no. 2 (2018): 1-10, https://doi.org/10.15294/rainbow.v7i2.29435.
} 
equivalence as follows: (1) Full equivalence occurs when the meaning in the source text is fully transferred to the target language. (2) The partial equivalence is divided into two. ${ }^{14}$ First, the partial equivalent of an increase in meaning occurs when additional information is embodied with new meanings that are not found in the source text. Second, the partial equivalent of a decrease in meaning occurs if some of the meanings in the source text are not manifested in the target language. (3) Non-equivalent is also divided into two. First, non-equivalent with different meanings occurs when the translator adds information in the source text with words that have different meanings in the target language. Second, meaningless nonequivalence occurs when the translator is not aware of the translation of the word in the source text so that the target language loses all the information contained in the source text.

Untranslatability or non-translation is the nature of any text, or speech in one language, for which no equivalent text or speech can be found in another language. ${ }^{15}$ The problem of nontranslation has been raised by various experts in translation, including Catford, who stated that linguistic non-translation is caused by differences in the source language and target language, while cultural non-translation is caused by the

14 Roger T. Bell, Translation and Translating: Theory and Practice (London: Longman, 1997), 6.

15 Jingjing Cui, "Untranslatability and the Method of Compensation," Theory and Practice in Language Studies 2, no. 4 (2012): 826-30, https://doi.org/10.4304/tpls.2.4.826-830. absence of relevant situational features in the target language. ${ }^{16}$ Nida provides a rich source of information on translation loss problems, particularly about the difficulties translators face when faced with terms or concepts in the source language that do not exist in the target language. Peter Newmark once spoke briefly about irregularities in translation. ${ }^{17}$

One of the articles discussing untranslatability and equivalence is Manzella. ${ }^{18} \mathrm{He}$ stated that one of the goals of the texts developed by the European Commission in various languages is to make comparisons between country-specific institutions and understand national practices easier. One of the terms discussed is "professionalità" which in English, this word is translated into "skills," "professionalism," "professionality," and "expertise." 'Skills' is by far the most commonly used word in the documents examined, followed by 'professionalism' and 'professionality,' all of which are thought to have distinct meanings, though this is not always the case. Finally, the term "expertise" has been used by EU translators in a significant amount of documentation. Each term has a different definition. The sense in which professionalità arose has

\footnotetext{
16 J. C. Catford, A Linguistik Theory of Translation (New York: Oxford University Press, 1974).

17 Peter Newmark, A Textbook of Translation (Hertfordshire: Prentice-Hall International, 1988).

18 Pietro Manzella, "Professionalità in International and Comparative Research: An Untranslatable Concept?," Translation Journal, 2019, https://www.translationjournal.net/January2019/professionalita-in-international-andcomparative-research-an-untranslatableconcept.html.
} 
given this language a dual definition, referring to both the worker and the job. The fact that professionalità is concerned with "both sides" (work and worker) seems to be overlooked in the English translations provided. Only one of the two intertwined meanings shared by professionalità is conveyed by the English renderings. The terms used in English, such as 'ability,' 'competence,' 'skill,' and 'knowledge,' emphasize the worker's hand, i.e., the qualities required to perform a job, with the dimension of work, i.e., the quality or importance of the role completed, which is lost in translation. As a result, using a one-word English approximation to translate the Italian professionalità may be misleading since the phrase in question has a broader sense than the English terms analyzed in this dataset.

The equivalence in translation focuses on the aspect of meaning, not on the aspect of sentence structure. In translation from the source language to the target language, there may be differences in sentence structure, as long as the meaning conveyed is the same or equivalent. Translation consists of reproducing in language the natural equivalent receptor of the source language message in terms of meaning and style. ${ }^{19}$

From some explanation above, the problems of untranslatability and language equivalence happens in any language. One field that faces the problem is
Mechanical Engineering which the English terminology has difficulty being translated into Bahasa Indonesia. Therefore, we need to search the factors of using English term preferences and explain the translation techniques in translating the terms into acceptable translation results. This research aims to find the acceptable translation that the experts can use in writing mechanical engineering article titles.

\section{B. Method}

The method used in this research was qualitative research. This research is also called contextual research. The terms used in the title of the article under study depend on the context of the research activities carried out by the researcher and the field of research being carried out. This means that the research to be carried out only takes a sample of the article's title that the author got in several mechanical engineering journals.

The data collected were titles that used bilingual language EnglishIndonesian in papers which the topic is mechanical engineering. The writer took the titles from many Indonesian mechanical engineering journals. The data then became proof that Indonesian papers often use English when the writers did not find the equivalence in the target language (Indonesian). Then they can be analyzed to find the technique to minimize the use of bilingual in Indonesian paper.

${ }^{19}$ Eugene Albert Nida and Charles Russell Taber, The Theory and Practice of Translation (Leiden: E. J. Brill, 2003), 12. 


\section{Results}

1. Factors of the use of English mechanical engineering terminology in Indonesian articles

The use of technical terms in Indonesian is rare for article writers in the field of mechanical engineering. They mostly use technical terms in English without translating them into Indonesian. This is because scholars, writers, and scientists in Mechanical Engineering also use terms in English more often as if it is something they usually do. There have been attempts from mechanical engineering experts to translate the terms of the Mechanical Engineering field into Indonesian. This can be seen from the work of Harsokoesoemo who wrote a book entitled 'Daftar Istilah Teknik Mesin: Inggris-Indonesia'. ${ }^{20}$

Apart from that, the book translators have also made efforts to translate these terms into Indonesian. For example, in the book 'Fundamentals of Engineering Thermodynamics' by Michael J. Moran. ${ }^{21}$ translated by Yulianto Sulistyo Nugroho into Termodinamika Teknik. ${ }^{22}$ The translator seeks to translate the various terms in the book by including the original terms so that it is hoped that readers, especially those who master mechanical

\footnotetext{
${ }^{20}$ Darmawan Harsokoesnoemo and Warsowiwoho Nastopo, Daftar Istilah Teknik Mesin: InggrisIndonesia (Bandung: Lab Elemen Mesin, Departemen Mesin ITB, 2004).

21 Michael J. Moran et al., Fundamentals of Engineering Thermodynamics (New York: John Wiley \& Sons, 1988).

22 Michael J. Moran and Howard N. Shapiro, Termodinamika Teknik, trans. Yulianto Sulistyo Nugroho and Adi Surjosusatyo, 2nd ed. (Jakarta: Erlangga, 2004).
}

engineering and write about the field, can use these translated terms instead of using terms in English.

The reality is that article writers in the field of mechanical engineering use bilingualism a lot in writing their article titles. This is caused by two factors, namely:

\section{a. The habit of experts using terms in English}

The main factor that the writer uses English elements in his writing is the bilingual factor. A person who has mastered more than one language, either actively or passively, tends to use or mix it with other languages. For example, the author of an article in the field of mechanical engineering mixes English into the Indonesian title. This is due to the language contact between English and Indonesian.

The number of foreign terms that have entered the Indonesian language is due to developments in science and technology. Therefore, Indonesian must adapt to the entry of foreign language elements. Unfortunately, not all terms in English, for example, find their correct equivalent in Indonesian. This causes scientists or writers to use these foreign terms, resulting in bilingualism. The factors that cause the inclusion of English elements, namely: (1) more popular, (2) more concise, (3) synonym, (4) more suitable and precise because it does not contain connotations bad. Nababan proposes other factors those are (5) richness of vocabulary, (6) accuracy of meaning, (7) added beauty, (8) more 
prestige, (9) more relaxed, and (10) led to intimacy. ${ }^{23}$ Of the ten factors that have been mentioned, the factors that cause the habituation of experts to use terms in English are (1) more concise, (2) synonym, and (2) more suitable and precise. Here's the description:

1) More concise

Some terms in mechanical engineering are special terms that sometimes become lengthy explanations when written in Indonesian. For example, the phrase 'shot peening' is commonly used in Indonesian language articles without translation than to be explained in length. 'Shot peening' is a cold working process on the surface of the material by spraying steel grains or fine glass on the material surface to obtain residual stress.

\section{2) Synonymy}

Several words have the same or nearly the same meaning called synonyms. When translated into Indonesian, an English term often creates double meanings because there are too many synonyms. This makes it difficult for our society to remember. Therefore, the English term is chosen to facilitate agreement if the translation equivalent is too many synonyms. For example, the word 'blower.'24 The term 'blower', if

\footnotetext{
23 Herianto Nababan, Mangatur Rudolf Nababan, and Riyadi Santosa, "Translation Techniques and Their Impact on the Readability of Translated Bible Stories for Children," Humanus 17, no. 2 (2019): 212-22,

https://doi.org/10.24036/humanus.v17i2.102729.

24 K Umurani and Habiburrahman Habiburrahman, "Studi Karakteristik Variasi Jumlah Sudu Impeler Pada Unjuk Kerja Blower Sentrifugal," Jurnal
}

translated into Indonesian is peniup, penghembus, alat peniup, pemompa, and tukang peniup. The variations of the translation results can result in different perceptions of the term is written in Indonesian. Therefore, the term blower is still written as-is to suit the title's context.

\section{3) More fit or precise}

In this case, the use of terms in English is deemed more appropriate or more suitable in the context of the article's title or discourse because no appropriate equivalent is found in Indonesian. The phrase 'shot peening' is often used in various article titles without information in Indonesian, for example, "Pengaruh Durasi Shot Peening terhadap Struktur Mikro dan Kekerasan Permukaan pada Aisi $316 l$ '. 25 'Shot peening' is equivalent with 'penumbukan peluru' in Indonesian. ${ }^{26}$ However, the term 'penumbukan peluru' is rarely used in the writing of article titles. If there are terms that have been found in Indonesian equivalents and are deemed suitable and acceptable, the authors usually write these terms in English with their equivalents in Indonesian. For example, the term 'friction welding,' which in Indonesian means las gesek is written in two languages to make it easier for readers to understand the term. An

\footnotetext{
Rekayasa Material, Manufaktur dan Energi 2, no. 2 (2019): 123-30, https://doi.org/10.30596/rmme.v2i2.3665.

25 Rizqi Ilmal Yaqin, "Pengaruh Durasi Shot Peening Terhadap Struktur Mikro dan Kekerasan Permukaaan pada AISI 316," Conference SENATIK STT Adisutjipto Yogyakarta 3 (2017): 16-20, https://doi.org/10.28989/senatik.v3i0.120.

26 Harsokoesnoemo and Nastopo, Daftar Istilah Teknik Mesin: Inggris-Indonesia, 211.
} 
example of a title using the term friction welding accompanied by a translation in Indonesian, namely "Penerapan Teknologi Las Gesek (Friction Welding) dalam Rangka Penyambungan Dua Buah Logam Baja Karbon St41 pada Produk Back Spring Pin'. ${ }^{27}$

\section{b. Problems of Untranslatability of the Terms}

Untranslatability is the nature of the text, or any speech in one language, for which no equivalent text or speech can be found in other languages. ${ }^{28}$ The problem of untranslatability has been raised by various experts, including Catford. $\mathrm{He}$ stated that linguistic untranslatability is caused by differences in the source language and target language. In contrast, cultural untranslatability is caused by the absence of relevant situational features in the target language. ${ }^{29}$ Nida provides a rich source of information on the problems of translation loss, particularly about the difficulties translators face when faced with terms or concepts in the source language that do not exist in the target language. ${ }^{30}$ Peter Newmark once spoke briefly about irregularities in translation. ${ }^{31}$

\footnotetext{
27 Nur Husodo, "Penerapan Teknologi Las Gesek (Friction Welding) dalam Rangka Penyambungan Dua Buah Logam Baja Karbon St41 pada Produk Back Spring Pin," Jurnal Energi dan Manufaktur 6, no. 1 (2013): 43-52.

${ }^{28}$ Amira D. Kashgary, "The Paradox of Translating the Untranslatable: Equivalence vs. NonEquivalence in Translating from Arabic into English," Journal of King Saud University Languages and Translation 23, no. 1 (2011): 4757, https://doi.org/10.1016/j.jksult.2010.03.001.

${ }^{29}$ Catford, A Linguistic Theory of Translation.

30 Eugene Albert Nida, Toward a Science of Translating (Leiden: E.J. Brill, 1964).

${ }^{31}$ Newmark, A Textbook of Translation.
}

In terms of mechanical engineering, the problem of non-translation often occurs. This is because many terms have been translated into Indonesian, but experts have not widely accepted them in the field. This is evidenced by the many variations in the translation results from one translator to another. For example a term of 'wettability' is translated into keterbasahan or sifat mampu basah. This kind of variation allows writers to use terms in English more often than in Indonesian so that it is hoped that readers, who are mainly from the same field, understand the meaning of the term more than if it is written in Indonesian.

\section{Efforts to reduce the use of bilingualism in writing article titles in the field of mechanical engineering}

Translation experts have made efforts to translate the English terms into Indonesian. This can be seen from the number of translation books in the field of mechanical engineering translated from English into Indonesian. The translators also come from a mechanical engineering background so they understand the terminology in that field. Translators have used some translation methods to produce translation results by the source language.

Some techniques can be used to create translation equivalence. One of the theories proposed is from Molina and Albir. ${ }^{32}$ According to them, translation

\footnotetext{
32 Lucía Molina and Amparo Albir, "Translation Techniques Revisited: A Dynamic and Functionalist Approach," Meta: Journal Des Traducteurs 47, no.
} 
techniques have five characteristics (1) translation techniques affect translation results; (2) the technique is classified by comparison to the source language text; (3) the technique is at the micro-level; (4) techniques are not related to each other but based on a certain context; (5) the technique is functional. They proposed 18 translation techniques as efforts to create translation equivalence.

In mechanical engineering terms, not all Molina and Albir's techniques can be used. Only some techniques are appropriate to create the translation equivalence from the source language to the target language.

\section{1) Amplification}

Amplification is a translation technique that makes explicit or paraphrases implicit information in the source language. ${ }^{33}$ Newmark calls it to paraphrase, which explains the meaning of a text segment because the segment contains implied or missing meaning, so it needs to be explained or paraphrased so that it becomes clearer. ${ }^{34}$ Some terms are translated using this technique, such as:

a) Heat

The word 'heat' is commonly translated into kalor rather than panas in Bahasa Indonesia, both in word and phrase. However, kalor and panas are used in the article title in Indonesian papers. Here are the examples:

$4 \quad$ (2002):

$498-512$

https://doi.org/10.7202/008033ar

${ }^{33}$ Molina and Albir.

${ }^{34}$ Newmark, A Textbook of Translation.
Analisis Perpindahan Panas dengan Konveksi Bebas dan Radiasi pada Penukar Panas Jenis Pipa dan Kawat. $^{35}$

Perpindahan Kalor Memanfaatkan Fluida Nano dalam Kurungan Jajaran Genjang. ${ }^{36}$

Perancangan dan Validasi Desain Alat Penukar Kalor Tipe Shell and Tube Menggunakan Computational Fluid Dynamics. ${ }^{37}$

Perpindahan kalor and perpindahan panas are the form of target language from 'heat transfer', while penukar panas and penukar kalor are the form of target language from 'heat exchanger'. There is a significant difference between the terms kalor and panas. Panas (heat) is a form of energy possessed by objects with relatively high temperatures, while kalor (heat) form of energy that flows due to temperature differences. Therefore, the use of both terms depends on the context of the discourse.

\section{b) Chamber}

In an Indonesian post, the word 'air chamber' is sometimes translated, and sometimes it is not. Here's an example:

\footnotetext{
${ }^{35}$ Made Arsana et al., "Analisis Perpindahan Panas Dengan Konveksi Bebas dan Radiasi Pada Penukar Panas Jenis Pipa dan Kawat," Jurnal Teknik Kimia 7, no. 1 (2013): 1-7, https://doi.org/10.33005/jurnal_tekkim.v7i1.444.

${ }^{36}$ Halim Mudia and Marhama Jelita, "Perpindahan Kalor Memanfaatkan Fluida Nano dalam Kurungan Jajaran Genjang," Jurnal Sains, Teknologi dan Industri 15, no. 2 (2018): 94-97, https://doi.org/10.24014/sitekin.v15i2.4590.

37 Eko Kiswoyo and Anwar IImar Ramadhan, "Perancangan dan Validasi Desain Alat Penukar Kalor Tipe Shell and Tube Menggunakan Computational Fluid Dynamics," Dinamika: Jurnal IImiah Teknik Mesin 8, no. 2 (2017): 39-46, https://doi.org/10.33772/djitm.v8i2.2407.
} 
Perancangan Chamber Variasi Bahan Elektroda untuk Pengukuran Ionisasi dari Sumber Tegangan Tinggi AC Dan DC. ${ }^{38}$

Using the amplification technique, 'chamber' is translated into ruang, but mostly it is translated into tabung. It is paraphrased when this word is combined with other words, for example, 'air chamber,' 'combustion chamber,' 'mini chamber' etc. The main meaning of those translations depends on the context of the phrase or sentence. Here are the examples of the variations of the 'chamber' term in Indonesia:

\section{Pengaruh Volume Tabung Tekan} terhadap Unjuk Kerja Pompa Hidram. ${ }^{39}$

The word "air chamber" is translated into tabung tekan in this title. The term "air chamber" refers to a chamber used to compress air to withstand the pressure produced by the hydram pump cycle.

Analisa Perancangan Ruang Bakar pada Pembangkit Listrik Mikro Turbin Gas Bahan Bakar LPG. ${ }^{40}$

\footnotetext{
${ }^{38}$ Marcellinus Christian Adi Nugroho, Abdul Syakur, and Agung Warsito, "Perancangan Chamber Variasi Bahan Elektroda untuk Pengukuran Ionisasi dari Sumber Tegangan Tinggi AC Dan DC," Transient: Jurnal Ilmiah Teknik Elektro 8, no. 1 (2019): $32-39$, https://doi.org/10.14710/transient.7.4.1113-1120.

39 Subroto and Shodiqin Shodiqin, "Pengaruh Volume Tabung Tekan Terhadap Unjuk Kerja Pompa Hidram," Media Mesin: Majalah Teknik Mesin 16, no. 2 (2015): 20-26, https://doi.org/10.23917/mesin.v16i2.1512.

40 Rudi Hermawan et al., "Analisa Perancangan Ruang Bakar pada Pembangkit Listrik Mikro Turbin Gas Bahan Bakar LPG," Prosiding Semnastek, 2017 , $1-12$ https://jurnal.umj.ac.id/index.php/semnastek/article/ view/1966
}

The word ruang bakar is used to translate the term "combustion chamber" in this title. A combustion chamber is that part of an internal combustion engine in which the fuel/air mix is burned.

\section{2) Borrowing}

Borrowing is a translation technique that is carried out by borrowing words or expressions from the source language. The borrowing can be pure (pure borrowing) without adjustment or naturalized borrowing with adjustments to spelling or pronunciation. ${ }^{41}$ The official dictionary in the target language is a measure of whether the word or expression is a loan or not. In mechanical engineering, many terms use this technique, such as:

Unjuk Kerja Thermosyphon dengan Variasi Fluida Kerja. ${ }^{42}$

Rancang Bangun Alat Pengumpul Panas Energi Matahari dengan Sistem Termosifon. ${ }^{43}$

Analisa Kekuatan Flange pada Sistem Pemipaan Primer Reaktor Triga 2000 Bandung. ${ }^{44}$

\footnotetext{
${ }^{41}$ Lidya Anita Afni Pantouw, Maya Pinkan Warouw, and Adriyani Marentek, "Penerjemahan Teks Medis Bahasa Inggris ke Bahasa Indonesia oleh Mahasiswa," Kajian Linguistik 6, no. 3 (2019): 1-15, https://doi.org/10.35796/kaling.6.3.2019.23631.

42 Arif Rochman Fachrudin, "Unjuk Kerja Thermosyphon dengan Variasi Fluida Kerja," Jurnal INTEKNA: Informasi Teknik dan Niaga 18, no. 2 (2018): 67-71.

43 Mulia Rahman and Budianto Lanya, "Rancang Bangun Alat Pengumpul Panas Energi Matahari dengan Sistem Termosifon," Jurnal Teknik Pertanian Lampung 2, no. 2 (2013): 95-104.

${ }^{44}$ Hendra Prihatnadi and Budi Santoso, "Analisa Kekuatan Flange pada Sistem Pemipaan Primer Reaktor Triga 2000 Bandung," Jurnal Perangkat Nuklir 5, no. 1 (2013): 36-41.
} 
Perancangan Kopling Flens pada Mesin Rebuild Ball Joint. ${ }^{45}$

The terms 'thermosyphon' and 'flange' are often used in Indonesian articles. Both terms are examples of pure borrowing translation techniques. At the same time, 'termosifon' and 'flens' are also sometimes used in Indonesian articles. Both terms are examples of naturalized borrowing since the spelling is adjusted with Indonesian spelling.

\section{3) Established Equivalence}

Established equivalence is a technique for using terms or expressions that are familiar / recognized in the dictionary of the target language as equivalents in the source-language text. This technique is similar to literal translation. In mechanical engineering, many terms use this technique, such as:

\section{Identifikasi Mechanical Properties} dari Bahan Daur Ulang Polystyrene. ${ }^{46}$

Analisis Steady State dan Dinamik pada Perencanaan Pengembangan Pembangkit Sistem Gorontalo. ${ }^{47}$

\footnotetext{
${ }^{45}$ Raja'amar Firdaus Prayogo Putra, "Perancangan Kopling Flens pada Mesin Rebuild Ball Joint," Digital Library of UPT Perpustakaan Sebelas Maret, 2018,

https://digilib.uns.ac.id/dokumen/61079/Perancanga n-Kopling-Flens-pada-Mesin-Rebuild-Ball-Joint.

${ }^{46}$ Taufik Nurhadi, Cahyo Budiyantoro, and Harini Sosiati, "Identifikasi Mechanical Properties dari Bahan Daur Ulang Polystyrene," JMPM (Jurnal Material dan Proses Manufaktur) 1, no. 1 (2017): 36-40, https://doi.org/10.18196/jmpm.v1i1.2758.

47 Frengki Eka Putra Surusa, Hadi Suyono, and Wijono Wijono, "Analisis Steady State Dan Dinamik Pada Perencanaan Pengembangan Pembangkit Sistem Gorontalo," Jurnal Arus Elektro Indonesia 2, no. 1 (2016): 9-14 https://jurnal.unej.ac.id/index.php/EJAEI/article/view/2319.
}

Two terms, 'mechanical properties' and 'steady state', have been translated in Indonesian using the established equivalent technique to be sifat mekanik and kondisi tunak. Mechanical properties are physical properties that a material exhibits upon the application of forces. While the steady-state is a state or condition of a system or process (such as one of the energy states of an atom) that does not change in time. The way those two terms are translated is based on the explanation. The term 'properties' cannot be translated into 'properti' in Indonesian. While 'steady state' is usually translated into kondisi mapan. However, kondisi tunak has become an accepted term.

\section{4) Calque}

Calque is included in the type of loan translation or borrowing, a translation technique that translates the morpheme or words of a language into morphemes or other language equivalent words. ${ }^{48}$ In mechanical engineering, many terms use this technique, such as:

Penerapan Teknologi Las Gesek (Friction Welding) dalam Rangka Penyambungan Dua Buah Logam Baja Karbon St41 pada Produk Back Spring Pin. ${ }^{49}$

Analisa Laju Aliran Fluida pada Mesin Pengering Konveyor Pneumatik dengan Menggunakan Simulasi CFD. ${ }^{50}$

\footnotetext{
48 Jack C. Richards and Richard W. Schmidt, Longman Dictionary of Language Teaching and Applied Linguistics (London: Routledge, 2013).

49 Husodo, "Penerapan Teknologi Las Gesek (Friction Welding) Dalam Rangka Penyambungan Dua Buah Logam Baja Karbon St41 Pada Produk Back Spring Pin."

${ }^{50}$ Imron Rosyadi et al., "Analisa Laju Aliran Fluida pada Mesin Pengering Konveyor Pneumatik
} 
'Friction welding' is translated into las gesek where 'friction' is gesek and 'welding' is las. Same as in the term laju aliran fluida, which is the translation form of 'fluid flow rate' where 'fluid' is fluida, 'flow' is aliran, and 'rate' is laju. The way the term translated is based on the literal structure from SL to TL.

\section{5) Literal Translation}

Literal translation is to translate a word or an expression word for word. ${ }^{51}$ This technique is the same as the formal equivalent technique proposed by Nida, but it is not the use of an equivalent which is already an official form. Many mechanical engineering terms are translated using the literal translation technique. It creates many variations of translation since the different translators translate into different terms. However, the meaning of the translation result is almost the same. For example:

\section{a) Wettability}

In an Indonesian post, the word 'wettability' is sometimes translated, and sometimes it is not. Here is the example:

Pengaruh Nilai Wettability pada Pool Boiling Heat Transfer Studi Kasus Hydrophobic, Hydrophilic dan Superhydrophilic. ${ }^{52}$

dengan Menggunakan Simulasi CFD," FLYWHEEL : Jurnal Teknik Mesin Untirta 2, no. 1 (2017): 48-51, https://doi.org/10.36055/fwl.v2i1.2587.

51 Molina and Albir, "Translation Techniques Revisited."

52 Bambang Joko Suroto, "Pengaruh Nilai Wettability Pada Pool Boiling Heat Transfer Studi Kasus Hydrophobic, Hydrophilic dan Superhydrophilic," Jurnal IImu dan Inovasi Fisika 1,

Using literal translation technique, 'wettability' is translated into keterbasahan, sifat mampu basah, or sifat kebasahan. The main meaning of those translation results is the same. Based on the dictionary, keterbasahan is the most used translation result. Here are the examples of the variations of the 'wettability' term in Indonesia:

Permasalahan yang telah diketahui secara meluas tetapi belum ditangani dengan optimum sampai sat ini adalah adanya perbedaan yang berarti antara data eksponen saturasi yang diukur pada kondisi atmosfer dan pada kondisi reservoir, akibat adanya perubahan sifat kebasahan (wettability) batuan, sedangkan fakta menunjukkan bahwa sebagian besar data tersebut diukur pada kondisi atmosfer. ${ }^{53}$

Sudut Kontak dan Keterbasahan Dinamis Kayu Samama pada Berbagai Pengerjaan Kayu.

b) Equilibrium

When the article writer uses the term 'equilibrium' in an Indonesian article, this term is sometimes translated, and sometimes, it is not. Here is the example:

Analisa Stabilitas dan Equilibrium Kapal Selam Midget 150 untuk Perairan Indonesia. ${ }^{54}$

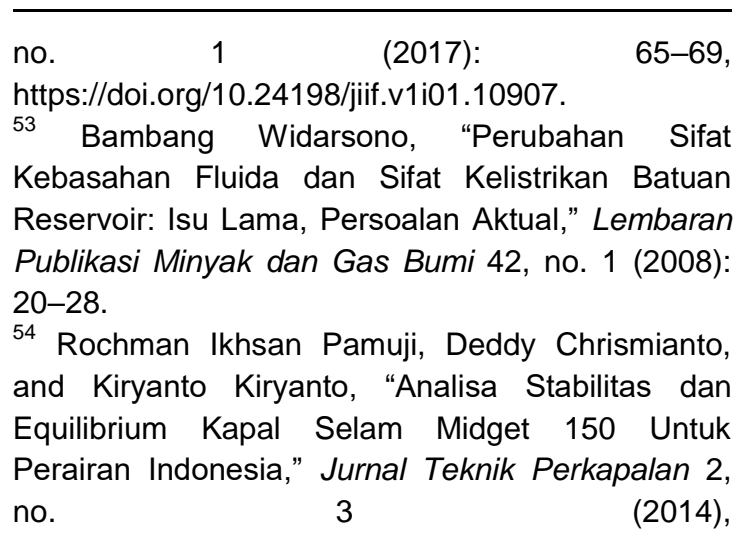


Using literal translation technique, 'equilibrium' is translated into ekuilibrium, kesetimbangan, or keadaan seimbang. The main meaning of those translation results is the same. Based on the dictionary, kesetimbangan is the most used translation result. Here are the examples of the variations of the 'equilibrium' term in Indonesia:

\section{Penentuan Kesetimbangan \\ Termodinamika dan Kinetika Adsorpsi Arang Aktif Tempurung Kelapa Sawit pada Zat Warna Reactive Red dan Direct Blue. ${ }^{55}$}

Penggunaan Ekuilibrium Nash dalam Penentuan Solusi Optimal Variabel Keputusan (Economic Order Quantity) dari Model Matematika Inventori. ${ }^{56}$

c) Preheat

When an Indonesian article writer uses the word 'preheat,' it is often translated and sometimes not. Preheat is the early process of heating. Here is the example:

Disain dan Pembuatan Alat Preheat Induksi pada Pengelasan Gesek Logam Dissimilar. ${ }^{57}$

https://ejournal3.undip.ac.id/index.php/naval/article/ view/5889.

${ }^{55}$ Rensy Aula Sari, M. Lutfi Firdaus, and Rina Elvia, "Penentuan Kesetimbangan, Termodinamika dan Kinetika Adsorpsi Arang Aktif Tempurung Kelapa Sawit Pada Zat Warna Reactive Red dan Direct Blue," Alotrop 1, no. 1 (2017): 10-14.

56 Rubono Setiawan, Henny Ekana Chrisnawati, and Yemi Kuswardi, "Penggunaan Ekuilibrium Nash dalam Penentuan Solusi Optimal Variabel Keputusan (Economic Order Quantity) dari Model Matematika Inventori," Jurnal Pendidikan Matematika dan Matematika SOLUSI 2, no. 4 (December 16, 2019): 322-26, https://doi.org/10.20961/jpmm.

${ }^{57}$ Reza Taufikur Rahman, Aris Widyo Nugroho, and Totok Suwanda, "Disain dan Pembuatan Alat
Using the literal translation technique, 'preheat' is translated into pemanasan awal. Here is the example of the translation result use in the Indonesian article:

Agar perbedaan suhu pada daerah yang bergesekan tidak terlalu besar, perlu dilakukan pemanasan awal /preheat pada logam dengan titik lebur yang lebih tinggi. ${ }^{60}$

From 18 translation techniques proposed by Molina \& Albir, six techniques can be applied to avoid bilingualism in the Indonesian papers' titles. The technique most used in mechanical engineering terminology is borrowing, especially natural borrowing. Since the terms can be replaced by the equivalent terms in the target language, natural borrowing becomes the best solution the get the equivalence of the terms. For example, thermosiphon is translated into "termosifon." Besides, some terms have got the equivalent meaning in Indonesian, such as heat, which is translated into "panas" or "kalor." The data examples show that the mechanical engineering terminology which is usually stated in English can be replaced by Indonesian. For example, the word equilibrium can be replaced by "kesetimbangan" or "ekuilibrium", depending on the translator's technique. The benefit of using translation techniques in translating the terms from English to Indonesian is to enrich the vocabulary in

Preheat Induksi pada Pengelasan Gesek Logam Dissimilar," JMPM (Jurnal Material dan Proses Manufaktur) 3, no. 2 (2019): 75-82, https://doi.org/10.18196/jmpm.3240. 
the mechanical engineering field, so the writer can use the Indonesian terms more than using English terms.

\section{Conclusion}

The field of mechanical engineering uses many special terms that are taken from English, not even translated so that the term remains in English. The use of special terms that cannot be translated into Indonesian is usually caused by inappropriate or unacceptable translation problems. This research has two results: (1) the factors that influence bilingualism in writing Indonesian language article titles in the field of Mechanical Engineering. The researcher found two factors, namely (a) the habit of experts using terms in English and (b) the problem of not translating the terms. The researcher analyzed various translation techniques used by translators, who mainly translated terms in the mechanical engineering field from the problems described. Here, the researcher uses the theory of Molina and Albir $^{37}$ to find the techniques used to translate mechanical engineering terms, namely (1) amplification, (2) borrowing, (3) established equivalence, (4) calque, and (5) literal translation. By using these techniques, many terms in the field of mechanical engineering find their equivalents in Indonesian.

\section{References}

Arsana, Made, Fathurrahman Malik, Wahyudi Priyono, Ali Alway, and Zuhdi Ma'sum. "Analisis Perpindahan Panas dengan Konveksi Bebas dan Radiasi pada Penukar Panas Jenis Pipa dan
Kawat." Jurnal Teknik Kimia 7, no. 1 (2013): 1-7. https://doi.org/10.33005/jurnal_tekki m.v7i1.444.

Baker, Colin. Bilingualism: Definitions and Distinctions. Foundation of Bilingual Education and Bilingualism. 5th ed. Bristol: Multilingual Matters, 2011.

Bell, Roger T. Translation and Translating: Theory and Practice. London: Longman, 1997.

Birner, Betty. "FAQ: Bilingualism । Linguistic Society of America," 2011. https://www.linguisticsociety.org/res ource/faq-what-bilingualism.

Catford, J. C. A Linguistik Theory of Translation. New York: Oxford University Press, 1974.

Chaer, Abdul, and Leonie Agustina. Sosiolinguistik Perkenalan Awal. Jakarta: Rineka Cipta, 2004.

Crystal, David. English as a Global Language. Cambridge: Cambridge University Press, 2012.

Cui, Jingjing. "Untranslatability and the Method of Compensation." Theory and Practice in Language Studies 2, no. 4 (2012): $826-30$. https://doi.org/10.4304/tpls.2.4.826830.

DeCapua, Andrea, and Ann Wintergerst. "Second-Generation Language Maintenance and Identity: A Case Study." Bilingual Research Journal 32, no. 1 (2009): 5-24. https://doi.org/10.1080/1523588090 2965672.

Fachrudin, Arif Rochman. "Unjuk Kerja Thermosyphon dengan Variasi Fluida Kerja." Jurnal INTEKNA: Informasi Teknik dan Niaga 18, no. 2 (2018): 67-71.

Handayani, Sri. "Analisis Ideologi Penerjemahan dan Penilaian Kualitas Terjemahan Istilah Kedokteran dalam Buku 'Lecture Notes on Clinical Medicine."' Master Thesis, Universitas Sebelas Maret, 2009. 
Harsokoesnoemo, Darmawan, and Warsowiwoho Nastopo. Daftar Istilah Teknik Mesin: InggrisIndonesia. Bandung: Lab Elemen Mesin, Departemen Mesin ITB, 2004.

Hermawan, Rudi, Eko Prasetyo, Damora Rhakasiwi, Agung Hartanto, and Erlanda Pane. "Analisa Perancangan Ruang Bakar pada Pembangkit Listrik Mikro Turbin Gas Bahan Bakar LPG." Prosiding Semnastek, 2017, 1-12. https://jurnal.umj.ac.id/index.php/se mnastek/article/view/1966.

Hirata, Andrea. The Rainbow Troops. Translated by Angie Kilbane. New York: Sarah Crichton Book, 2009.

Husodo, Nur. "Penerapan Teknologi Las Gesek (Friction Welding) dalam Rangka Penyambungan Dua Buah Logam Baja Karbon St41 Pada Produk Back Spring Pin." Jurnal Energi dan Manufaktur 6, no. 1 (2013): 43-52.

Javier, Rafael Art. The Bilingual Mind: Thinking, Feeling and Speaking in Two Languages. New York: Springer Science \& Business Media, 2007.

Joko Suroto, Bambang. "Pengaruh Nilai Wettability pada Pool Boiling Heat Transfer Studi Kasus Hydrophobic, Hydrophilic dan Superhydrophilic." Jurnal IImu dan Inovasi Fisika 1, no. 1 (2017): 65-69. https://doi.org/10.24198/jiif.v1i01.10 907.

Kashgary, Amira D. "The Paradox of Translating the Untranslatable: Equivalence vs. Non-Equivalence in Translating from Arabic into English." Journal of King Saud University - Languages and Translation 23, no. 1 (2011): 47-57. https://doi.org/10.1016/j.jksult.2010. 03.001 .

Kiswoyo, Eko, and Anwar Ilmar Ramadhan. "Perancangan dan
Validasi Desain Alat Penukar Kalor Tipe Shell and Tube Menggunakan Computational Fluid Dynamics." Dinamika: Jurnal Ilmiah Teknik Mesin 8, no. 2 (2017): 39-46. https://doi.org/10.33772/djitm.v8i2.2 407.

Manzella, Pietro. "Professionalità in International and Comparative Research: An Untranslatable Concept?" Translation Journal, 2019.

https://www.translationjournal.net/Ja nuary-2019/professionalita-ininternational-and-comparativeresearch-an-untranslatableconcept.html.

Moeller, Aleidine J., and Theresa Catalano. "Foreign Language Teaching and Learning." In International Encyclopedia of the Social \& Behavioral Sciences, 32732 Elsevier, 2015. https://doi.org/10.1016/B978-0-08097086-8.92082-8.

Molina, Lucía, and Amparo Albir. "Translation Techniques Revisited: A Dynamic and Functionalist Approach." Meta: Journal Des Traducteurs 47, no. 4 (2002): 498512.

https://doi.org/10.7202/008033ar.

Moran, Michael J., and Howard N. Shapiro. Fundamentals of Engineering Thermodynamics. New York: John Wiley \& Sons, 1988.

Moran, Michael J., and Howard N. Shapiro. Termodinamika Teknik. Translated by Yulianto Sulistyo Nugroho and Adi Surjosusatyo. 2nd ed. Jakarta: Erlangga, 2004.

Mudia, Halim, and Marhama Jelita. "Perpindahan Kalor Memanfaatkan Fluida Nano dalam Kurungan Jajaran Genjang." Jurnal Sains, Teknologi dan Industri 15, no. 2 (2018): 94-97. https://doi.org/10.24014/sitekin.v15i 2.4590 . 
Nababan, Herianto, Mangatur Rudolf Nababan, and Riyadi Santosa. "Translation Techniques and Their Impact on the Readability of Translated Bible Stories for Children." Humanus 17, no. 2 (2019): 212-22. https://doi.org/10.24036/humanus.v $17 i 2.102729$.

Nafisah, Nuharani Dyah, Rudi Hartono, and Issy Yuliasri. "Translation Methods and Degree of Equivalence in English-Indonesian Translation of Leo Tolstoy's "God Sees the Truth But Waits"." Rainbow: Journal of Literature, Linguistics and Culture Studies 7, no. 2 (2018): 1-10. https://doi.org/10.15294/rainbow.v7i 2.29435 .

Newmark, Peter. A Textbook of Translation. Hertfordshire: PrenticeHall International, 1988.

Nida, Eugene Albert, Toward a Science of Translating. Leiden: E.J. Brill, 1964.

Nida, Eugene Albert, and Charles Russell Taber. The Theory and Practice of Translation. Leiden: E. J. Brill, 2003.

Nugroho, Marcellinus Christian Adi, Abdul Syakur, and Agung Warsito. "Perancangan Chamber Variasi Bahan Elektroda untuk Pengukuran Ionisasi dari Sumber Tegangan Tinggi AC dan DC." Transient: Jurnal IImiah Teknik Elektro 8, no. 1 (2019): 32-39. https://doi.org/10.14710/transient.7. 4.1113-1120.

Nurhadi, Taufik, Cahyo Budiyantoro, and Harini Sosiati. "Identifikasi Mechanical Properties dari Bahan Daur Ulang Polystyrene." JMPM (Jurnal Material dan Proses Manufaktur) 1, no. 1 (2017): 36-40. https://doi.org/10.18196/jmpm.v1i1.2 758.

Pamuji, Rochman Ikhsan, Deddy Chrismianto, and Kiryanto Kiryanto. "Analisa Stabilitas dan Equilibrium Kapal Selam Midget 150 untuk Perairan Indonesia." Jurnal Teknik
Perkapalan 2, no. 3 (2014). https://ejournal3.undip.ac.id/index.p $\mathrm{hp} /$ naval/article/view/5889.

Pantouw, Lidya Anita Afni, Maya Pinkan Warouw, and Adriyani Marentek. "Penerjemahan Teks Medis Bahasa Inggris ke Bahasa Indonesia oleh Mahasiswa." Kajian Linguistik 6, no. 3 (2019): 1-15. https://doi.org/10.35796/kaling.6.3.2 019.23631.

Prihatnadi, Hendra, and Budi Santoso. "Analisa Kekuatan Flange pada Sistem Pemipaan Primer Reaktor Triga 2000 Bandung." Jurnal Perangkat Nuklir 5, no. 1 (2013): 36-41.

Putra, Raja'amar Firdaus Prayogo. "Perancangan Kopling Flens pada Mesin Rebuild Ball Joint." Digital Library of UPT Perpustakaan Sebelas $\quad$ Maret, 2018. https://digilib.uns.ac.id/dokumen/610 79/Perancangan-Kopling-Flenspada-Mesin-Rebuild-Ball-Joint.

Rahman, Mulia, and Budianto Lanya. "Rancang Bangun Alat Pengumpul Panas Energi Matahari dengan Sistem Termosifon." Jurnal Teknik Pertanian Lampung 2, no. 2 (2013): 95-104.

Rahman, Reza Taufikur, Aris Widyo Nugroho, and Totok Suwanda. "Disain dan Pembuatan Alat Preheat Induksi pada Pengelasan Gesek Logam Dissimilar." JMPM (Jurnal Material dan Proses Manufaktur) 3, no. 2 (2019): 75-82. https://doi.org/10.18196/jmpm.3240.

Richards, Jack C., and Richard W. Schmidt. Longman Dictionary of Language Teaching and Applied Linguistics. London: Routledge, 2013.

Rosyadi, Imron, Agung Sudrajad, Dhimas Satria, Yusvardi Yusuf, and Kurnia Tri Wijaya. "Analisa Laju Aliran Fluida pada Mesin Pengering Konveyor Pneumatik dengan Menggunakan Simulasi CFD." 
FLYWHEEL: Jurnal Teknik Mesin Untirta 2, no. 1 (2017): 48-51. https://doi.org/10.36055/fwl.v2i1.2587.

Sari, Rensy Aula, M. Lutfi Firdaus, and Rina Elvia. "Penentuan Kesetimbangan, Termodinamika dan Kinetika Adsorpsi Arang Aktif Tempurung Kelapa Sawit pada Zat Warna Reactive Red dan Direct Blue." Alotrop 1, no. 1 (2017): 1014.

Setiawan, Rubono, Henny Ekana Chrisnawati, and Yemi Kuswardi. "Penggunaan Ekuilibrium Nash dalam Penentuan Solusi Optimal Variabel Keputusan (Economic Order Quantity) dari Model Matematika Inventori." Jurnal Pendidikan Matematika dan Matematika SOLUSI2, no. 4 (2019): 322-26.

https://doi.org/10.20961/jpmm.

Subroto, and Shodiqin Shodiqin. "Pengaruh Volume Tabung Tekan Terhadap Unjuk Kerja Pompa Hidram." Media Mesin: Majalah Teknik Mesin 16, no. 2 (2015): 20 26.

https://doi.org/10.23917/mesin.v16i2 .1512 .

Surusa, Frengki Eka Putra, Hadi Suyono, and Wijono Wijono. "Analisis Steady State dan Dinamik pada Perencanaan Pengembangan Pembangkit Sistem Gorontalo." Jurnal Arus Elektro Indonesia 2, no. 1 (2016): 9-14. https://jurnal.unej.ac.id/index.php/EJAEl/article/view/2319.

Umurani, K, and Habiburrahman Habiburrahman. "Studi Karakteristik Variasi Jumlah Sudu Impeler pada Unjuk Kerja Blower Sentrifugal." Jurnal Rekayasa Material, Manufaktur dan Energi 2, no. 2 (2019): 123-30. https://doi.org/10.30596/rmme.v2i2. 3665.
Utami SK, Nur. "Cultural Untranslatability: A Study on the Rainbow Troops." Celt: A Journal of Culture, English Language Teaching \& Literature 14, no. 1 (2014): 48-62. https://doi.org/10.24167/celt.v14i1.56.

Verplaetse, L. S., and E. Schmitt. "Bilingualism and Learning." In International Encyclopedia of Education (Third Edition), edited by Penelope Peterson, Eva Baker, and Barry McGaw, 355-60. Oxford: Elsevier, 2010. https://doi.org/10.1016/B978-0-08044894-7.00508-X.

Widarsono, Bambang. "Perubahan Sifat Kebasahan Fluida dan Sifat Kelistrikan Batuan Reservoir: Isu Lama, Persoalan Aktual." Lembaran Publikasi Minyak dan Gas Bumi 42, no. 1 (2008): 20-28.

Yaqin, Rizqi IImal. "Pengaruh Durasi Shot Peening terhadap Struktur Mikro dan Kekerasan Permukaaan pada AISI 316." Conference SENATIK STT Adisutjipto Yogyakarta 3 (2017): 16-20. https://doi.org/10.28989/senatik.v3i0 .120 . 